Hydrol. Earth Syst. Sci., 17, 2053-2067, 2013

www.hydrol-earth-syst-sci.net/17/2053/2013/

doi:10.5194/hess-17-2053-2013

(C) Author(s) 2013. CC Attribution 3.0 License.

\title{
Water-use dynamics of a peat swamp forest and a dune forest in Maputaland, South Africa
}

\author{
A. D. Clulow ${ }^{1}$, C. S. Everson ${ }^{1}$, J. S. Price ${ }^{2}$, G. P. W. Jewitt ${ }^{1}$, and B. C. Scott-Shaw ${ }^{1}$ \\ ${ }^{1}$ Centre for Water Resources Research, School of Agriculture, Engineering and the Environment, \\ University of KwaZulu-Natal, Private Bag X01, Scottsville, Pietermaritzburg 3209, South Africa \\ ${ }^{2}$ Department of Geography \& Environmental Management, University of Waterloo, Waterloo, Ontario, N2L 3G1, Canada
}

Correspondence to: A. D. Clulow (clulowa@ukzn.ac.za)

Received: 24 January 2013 - Published in Hydrol. Earth Syst. Sci. Discuss.: 5 February 2013

Revised: 6 April 2013 - Accepted: 30 April 2013 - Published: 31 May 2013

\begin{abstract}
Peat swamp forests are the second rarest forest type found in South Africa while dune forests have been under severe threat through mining and agriculture. Both forest types exist in the conservation area, and World Heritage site, known as the iSimangaliso Wetland Park on the East coast of South Africa. The area is prone to severe droughts (Taylor et al., 2006) and recent attempts to understand the local water balance revealed that there was insufficient information on the water use of the indigenous forests of the area. The peat swamp forest and dune forest sites studied in this research were located within close proximity to each other, yet, are characterised by different landscape positions in terms of water availability. The coastal dune forest soil profile was generally dry and sandy and the tree roots did not have access to the water table. In contrast the peat swamp forest is located in an interdunal wetland where the trees have permanent access to water. The climate at both sites is subtropical with a mean annual precipitation of $1200 \mathrm{~mm} \mathrm{yr}^{-1}$. However, over 20 months of measurement, the first summer (October 2009 to March 2010) was drier (424 versus $735 \mathrm{~mm}$ ) than the second summer (October 2010 to March 2011) emphasising the variability of the rainfall in the area and providing a wide range of conditions measured.
\end{abstract}

The sap flow of an evergreen, overstory Syzygium cordatum and a semi-deciduous, understory Shirakiopsis elliptica were measured in the peat swamp forest using the heat ratio method. The Syzygium cordatum water use was not highly seasonal and the daily maximum water use ranged from approximately $30 \mathrm{Ld}^{-1}$ in winter to $45 \mathrm{Ld}^{-1}$ in summer whereas the Shirakiopsis elliptica water use was more seasonal at $2 \mathrm{Ld}^{-1}$ in winter and $12 \mathrm{Ld}^{-1}$ in summer. The water use of the Syzygium cordatum was not influenced by seasonal rainfall variations and was actually higher in the drier summer (October 2009 to March 2010). Three trees of different heights were monitored in the same way in the dune forest and the water use found to be highly seasonal. Over the entire measurement period, the water use was highest for an emergent Mimusops caffra ( 5 to $45 \mathrm{Ld}^{-1}$ ), whereas the water use of the Eugenia natalitia ( 2 to $28 \mathrm{Ld}^{-1}$ ) and Drypetes natalensis $\left(1\right.$ to $\left.4 \mathrm{Ld}^{-1}\right)$ was lower. At the dune forest, the water use was highest in the wetter summer due to the reliance of the trees on rainfall to recharge the soil water. A split-line regression showed that on average, soil water limited tree water use $64 \%$ of the time over the measurement period at the dune forest. For modelling tree water use at the dune forest, it was concluded that a two-stage model, taking soil water content into account (from multiple sampling points), would be necessary.

\section{Introduction}

There has been extensive research on the comparative water use of introduced trees and the indigenous vegetation they replace in South Africa (Dye, 2001; Everson et al., 2008; Gush and Dye, 2006, 2009). However, most of the work does not extend to indigenous tree water use and there is a general dearth of information around the subject (Dye et al., 2008). Where information is available, climatic means, geographic location and soil water availability introduce doubt as to the transferability of results from one area to the next. Peat swamp forest (PSF) and dune forest (DF) transpiration 
rates measured in this research are the first of their kind in South Africa and form a valuable contribution to the existing indigenous tree water-use information. Indeed, the authors are unaware of any comparable water-use estimates from either of these vegetation types internationally.

The recent drive in South Africa to understand indigenous water use stems primarily from the hydrologically extreme change in land use that has taken place in South Africa since the early 1900s. The result of this change has brought about a shift in the water balance (Dye et al., 2008). For example, in some areas shallow rooted, seasonally dormant grasslands were replaced by deep rooted, evergreen forest plantations with high leaf areas. Commercial forestry plantations of exotic species have been associated with increasing the green water (water lost by evaporation) and decreasing the blue water (water in rivers and dams) in areas across South Africa (Calder, 1999; Jewitt, 2006). The first forest plantations were established in 1875 in the high rainfall areas of the country (Gush et al., 2002). During the course of the 1900 s, the area under forestry grew to 1.5 million hectares, approximately $1.5 \%$ of the country's land cover, as the demand for wood increased. It was realised that forestry posed a threat to the availability of blue water, and since 1968 there have been recommendations and legal requirements associated with forestry as a result of its water use (Dye and Versfeld, 2007). Water-use licenses and monthly water costs associated with forestry (DWAF, 2004) and strict environmental legislation associated with riparian zones have been implemented (FIEC, 1995).

The Eastern Shores area of the St. Lucia estuary, in the Maputaland area of KwaZulu-Natal, was planted to exotic commercial pine plantations in the 1950s (Dominy, 1992). However, since the avulsion of the Umfolozi River from Lake St. Lucia in 1952, the importance of groundwater recharge and the dependence of the lake water levels and wetland areas on groundwater became critical (Taylor et al., 2006). With a growing understanding of the importance of the regional ecology and the potential for tourism, the Greater St. Lucia Wetland Park (the iSimangaliso Wetland Park since 2007 and a RAMSAR and World Heritage Site) was protected from dune mining proposals in the 1990s. However, the negative impact of commercial forestry on water resources and specifically the potential of the trees to deplete groundwater resulted in a decision to remove the plantations from the Eastern Shores area. This was successfully undertaken between 1991 and 2004 and the only evidence of commercial forestry across the dunes and around wetlands are the remaining tree stumps.

However, despite the removal of the commercial plantations, lower than average rainfall near the lake exacerbated the wider drought conditions since 2001, and salinity levels in the Lake have been critically high at times and have threatened species survival (Mackay et al., 2010). Cyrus et al. (2010) stated that remedial action is required to enable the proper functioning of the estuary and therefore proposed the establishment of a permanent link between the Umfolozi River and the lake to supply fresh water and reduce salinity levels. The healthy functioning of the estuary is clearly in the balance due to anthropogenic influences that have severely affected the water balance of the system. A water management strategy is therefore critical to the future health of the estuary. In addition, of the indigenous forests in KwaZulu-Natal, Eeley et al. (1999) particularly include swamp and dune forests as being those most at risk due to climate change. Even more so, peat swamp forests are at risk of invasion or succession by upland species in response to lowering of the water table, the drying out of peat and the increased potential for peat fires. It was during the course of a recent research project (Water Research Commission Project K5/1704) to address the water management of the Eastern Shores area and the implications of climate change to the area that it was necessary to determine the water balance. However, it was apparent that there is little or no information on the actual water use from the natural vegetation types of the area. Total evaporation (ET), which includes transpiration and soil water evaporation, is a dominant component of the water balance in South Africa (Linacre, 1976; Everson et al., 2001, 2011). It was therefore determined that there is a need to measure the tree transpiration, which dominates in forests (Bosch and Hewlett, 1982), to better understand the dynamics of these two important forest types found within the area.

In terms of contribution to water-balance modelling, an improved understanding of tree transpiration dynamics and limits of individual (and dominant) species, was considered more useful than an overall ET estimate of each forest type, which is the sum of the water use from the trees, undergrowth and soil. The dynamics of the tree transpiration (which dominates in forests) can be lost in a single measurement of ET due to the inclusion of the other components with their particular dynamics (undergrowth and soil). In addition, the absolute results of ET from each forest type are site specific and therefore not necessarily transferable to other forest areas, whereas an understanding of dynamics and limits of individual tree transpiration (hereafter referred to as water use) provide concepts transferable to PSFs and DFs in other areas. Therefore, the aim of this research was to determine daily tree water use in a PSF and a nearby DF, to understand the water-use dynamics in response to seasonal changes with additional measurements of soil water fluctuations within each forest type.

\subsection{The study area}

The study area (Fig. 1) was located in the Eastern Shores area of the iSimangaliso Wetland Park, which was declared South Africa's first UNESCO World Heritage Site in 1999 (Taylor et al., 2006). It lies adjacent to Lake St. Lucia and within the St. Lucia Ramsar Site designated in 1986 (Taylor, 1991). It is a premier tourist destination contributing to the economy 


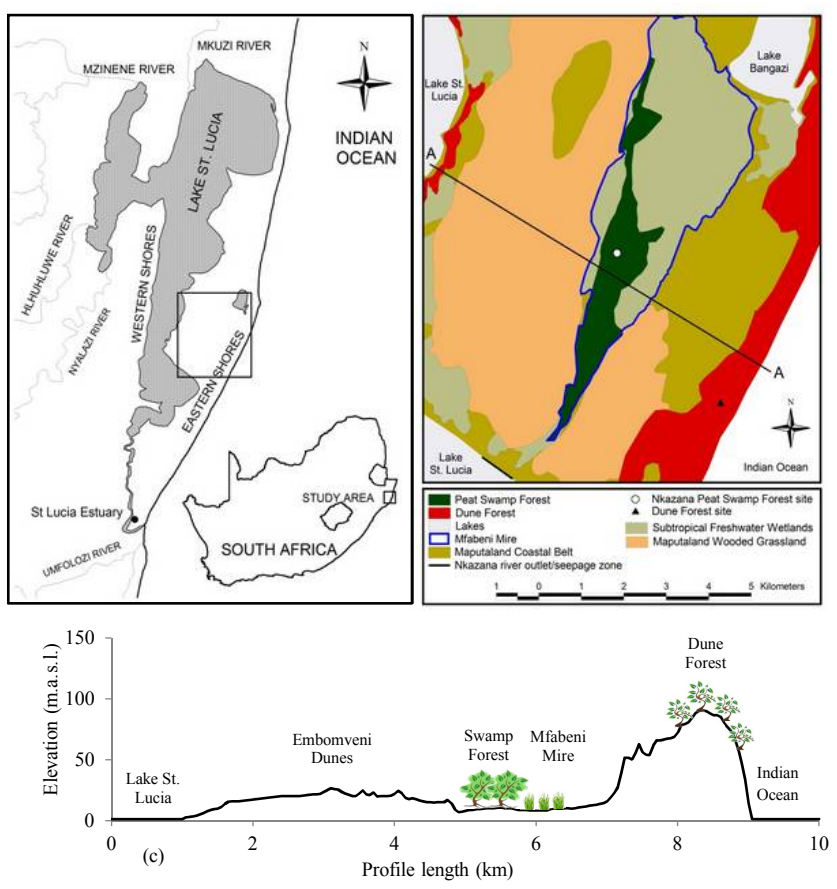

Fig. 1. (a) Location of Lake St. Lucia and research area in South Africa, (b) the Nkazana peat swamp forest site and the Dune Forest site with the distribution of the vegetation on the Eastern Shores and (c) a cross-sectional profile of transect A-A in Fig. $1 \mathrm{~b}$.

of the surrounding communities and the town of St. Lucia (Whitfield and Taylor, 2009).

The iSimangaliso Wetland Park has a subtropical climate and lies in a summer rainfall area (Schulze et al., 2008). There is a steep rainfall gradient from east to west and at the coastline the mean annual precipitation exceeds $1200 \mathrm{~mm} \mathrm{yr}^{-1}$ but drops to only $900 \mathrm{~mm} \mathrm{yr}^{-1} 10 \mathrm{~km}$ to the west at Fanies Island (Taylor et al., 2006). Taylor et al. (2006) further reported that the temporal variability of the rainfall gives rise to severe wet and dry periods in Maputaland and during this study there was a well-reported drought in the region.

The Eastern Shores area is flanked by Lake St. Lucia to the west and the Indian Ocean to the east (Fig. 1b). The coastal dunes, where the DF site is situated, are among the tallest forested coastal sand dunes in the world (Pooley, 2003); to the west the lower, undulating Embomveni Dunes border Lake St. Lucia. An ancient interdunal drainage line that forms the Mfabeni Mire lies between these two dune areas (Fig. 1c). The Mfabeni Mire is drained by the perennial Nkazana Stream which flows freshwater into Lake St. Lucia and is an important source during droughts (Vrdoljak and Hart, 2007). Organic matter and sediment at times has accumulated in the Mfabeni Mire over the past $45000 \mathrm{yr}$, forming one of South Africa's largest peatlands and one of the oldest active peatlands in the world (Grundling et al., 1998). The Mfabeni Mire is approximately $8 \mathrm{~km}$ long (north-south direction) and $4 \mathrm{~km}$ at its widest point (east-west direction). The Nkazana PSF forms part of the Mfabeni Mire and runs down the western side of the Mire (Fig. 1). The Nkazana PSF and the DF fall within the Indian Ocean Coastal Belt Biome, described as being a mixed, seasonal grassland community (Mucina and Rutherford, 2006). The former is further classified by von Maltitz et al. (2003) and Mucina and Rutherford (2006) as an Azonal Forest (AII: Swamp Forest) and the latter a Northern Coastal Forest (VII1: KwaZulu-Natal Coastal Forest).

\subsection{The study sites}

The Nkazana PSF site $\left(28^{\circ} 10.176^{\prime} \mathrm{S}, 32^{\circ} 30.070^{\prime} \mathrm{E}\right)$ lies on the western boundary of the Mfabeni Mire and runs in a north-south direction for approximately $7 \mathrm{~km}$. A detailed vegetation survey of the PSF has been described by Venter (2003). Wessels (1997) classified the swamp forests of the area into three logical subgroupings based on dominant species, stand density and basal areas. The Syzygium cordatum subgroup is characterised by an irregular, broken canopy of predominantly Syzygium cordatum trees (known locally as the Water Berry) of up to $30 \mathrm{~m}$, emerging above an intermediate canopy of approximately $6-15 \mathrm{~m}$. The Nkazana PSF site posed several challenges due to general inaccessibility as well as the dense Nephrolepis biserrata fern that covers the forest floor to a height of $2.5 \mathrm{~m}$ and the Stenochlaena tenuifolia (Blechnaceae) fern that festoons the tree stems. The ground at the PSF site was wet and soft with a $0.3 \mathrm{~m}$ layer of peat over sand. However, the peat is over $2 \mathrm{~m}$ thick in places within the Nkazana PSF (hereafter referred to as PSF only). The two trees instrumented for monitoring sap flow were located within this widely spread Syzygium cordatum subgroup of the PSF at its broadest point (approximately $1 \mathrm{~km}$ ) to minimise edge effects. An overstory tree (Syzygium cordatum) and a mid-canopy tree (Shirakiopsis elliptica) were instrumented. Syzygium cordatum is the most common swamp forest tree across Maputaland, likely due to its fire and hydroperiod tolerance (Wessels, 1997). Other tree species found in the immediate vicinity of the monitored trees included: Macaranga capensis, Bridelia micrantha, Tarenna pavettoides and Stenochlaena tenuifolia. The leaf area index (LAI) beneath the ferns and trees was approximately 7.2 and below the trees approximately 3.3 (suggesting a near-closed canopy) throughout the year (Fig. 2). The depth to water table was $<1.0 \mathrm{~m}$ and the trees had permanent access to groundwater.

The coastal dunes are flanked to the east by the Indian Ocean and to the west by the Mfabeni Mire. The dunes rise steeply from the beach to an elevation of up to $80 \mathrm{ma}$ a.s.1. and drop-off gradually to the Mfabeni Mire to the west (Fig. 1c). The vegetation is mainly a mixed species DF with isolated areas of grassland. The DF site $\left(28^{\circ} 12.017^{\prime} \mathrm{S}\right.$, $32^{\circ} 31.633^{\prime} \mathrm{E}$ ) has a rich diversity of tree species. Three different tree species (Drypetes natalensis, Eugenia natalitia 


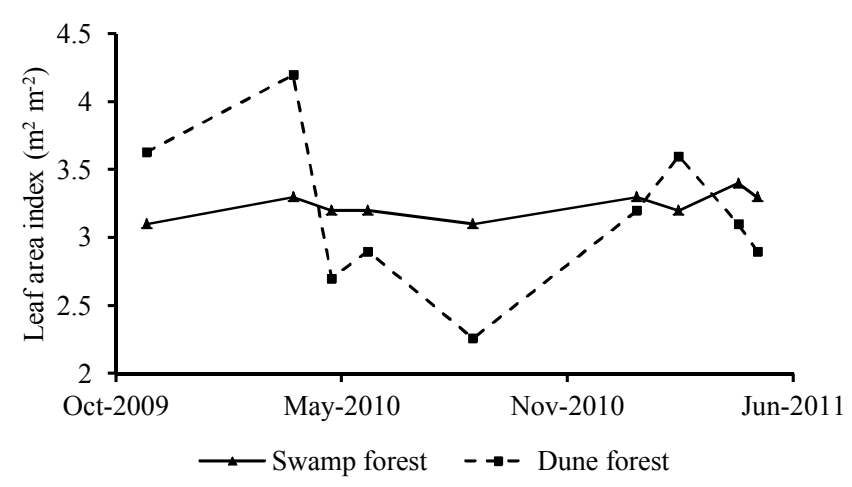

Fig. 2. Leaf area index measured at the swamp forest (above the ferns) and dune forest sites.

and Mimusops caffra) were instrumented for monitoring of sap flow. These trees were selected because they are common DF trees representative of the coastal dune forests of Maputaland and due to their proximity to each other, which was a limitation of the sap flow system installed. They also represented different height categories within the DF with the Drypetes natalensis being the shortest and therefore mainly shaded within the canopy (understory), the $E u$ genia natalitia partly shaded (mid-canopy), and the Мimusops caffra emergent or fully exposed to solar irradiance (overstorey). Other dominant tree species found around those instrumented include Strychnos gerrardii, Garcinia livingstonei, and Casearia gladiiformis. The LAI was between 2.3 in winter and 4.3 in summer (Fig. 2). The DF soils are well drained and the tree roots did not have access to the water table.

\section{Methodology}

An automatic weather station provided climatic data from the nearby ( $3 \mathrm{~km}$ from the PSF site, $5 \mathrm{~km}$ from the DF site) Mfabeni Mire where rainfall (TE525, Texas Electronics Inc., Dallas, Texas, USA), air temperature (HMP45C, Vaisala Inc., Helsinki, Finland), relative humidity (HMP45C, Vaisala Inc., Helsinki, Finland), solar irradiance (LI-200, LI-COR, Lincoln, Nebraska, USA), net radiation (NR-Lite, Kipp \& Zonen, Delft, the Netherlands) wind speed and direction (Model 03002, R.M. Young, Traverse city, Michigan, USA) were measured. The raingauge was mounted so that the orifice was at a height of $1.2 \mathrm{~m}$ above the ground and the remaining sensors $2 \mathrm{~m}$ above ground level. Vapour pressure deficit (VPD) was calculated from the air temperature and relative humidity according to Savage et al. (1997). The climatic data were averaged over $30 \mathrm{~min}$ intervals from observations made every $10 \mathrm{~s}$ and stored on a data logger (CR1000, Campbell Scientific Inc., Logan, Utah, USA). The FAO-56 grass reference evaporation $\left(\mathrm{ET}_{\mathrm{r}}\right)$ was calculated from the climatic data according to Allen et al. (2006) at an hourly interval and summed to a daily level.

A heat pulse velocity system (HPV) using the heat ratio method as described by Burgess et al. (2001), was used to estimate sap flow at various depths across the sapwood of selected trees over 20 months from September 2009 to early May 2011. The site for measurement in each forest was selected based on trees that were representative in terms of species, size, canopy height as well as proximity to each other due to cable length limitations of the HPV system. Tree species instrumented at each site are representative of either PSFs or DFs in Maputaland (Boon, 2010). An assessment of bark and cambium depth were made and suitable insertion depths (Table 1) selected for optimal measurement within the sapwood of the trees using an increment borer and Methyl Orange. A line-heater probe, $(8 \mathrm{~cm}$ long and of $0.18 \mathrm{~cm}$ outside-diameter stainless steel tubing) enclosed a constantan filament that, when powered from a $100 \mathrm{Ah}$, deep cycle battery for $0.5 \mathrm{~s}$ provided a heat source. A pair of thermocouple (TC) probes (consisting of type T copper-constantan thermocouples embedded in $0.2 \mathrm{~cm}$ outside-diameter PTFE tubing) was used to measure temperatures $0.5 \mathrm{~cm}$ upstream and downstream of the heater probe. Hourly measurements (CR1000, Campbell Scientific Inc., Logan, Utah, USA) were recorded from 4 September 2009 to 4 May 2011. Up to 24 TCs were multiplexed (AM16/32, Campbell Scientific Inc., Logan, Utah, USA) allowing 12 measurements at various sapwood depths and across tree species. The number of trees monitored was limited due to equipment costs but a full sap flow system allowing 12 measurement pairs was available for each forest type. At the DF the tree stem diameters were all $<0.17 \mathrm{~m}$ and four TC pairs in each tree was suitable to measure sap flow at different depths across the sapwood. However, at the PSF, the Syzygium cordatum stem diameter was $0.43 \mathrm{~m}$ and sap flow was measured at four depths across the sapwood on the eastern side of the stem and at four depths across the sapwood on the western side of the stem in case of differences in the thick stem of the tree. The remaining four pairs were installed in a nearby mid-canopy tree (Shirakiopsis elliptica) which has a smaller stem diameter $(0.081 \mathrm{~m})$.

The automated hourly measurement sequence began by measuring each thermocouple 10 times to provide an accurate initial temperature. Following the release of a pulse of heat, the downstream and upstream temperatures were measured 60 times between 60 and 100 s (Burgess et al., 2001). The heat pulse velocity $\left(V_{\mathrm{h}}\right)$ was calculated from

$V_{\mathrm{h}}=\frac{k}{x} \ln \left(\frac{v_{1}}{v_{2}}\right) 3600$,

where $k$ is the thermal diffusivity of green (fresh) wood, $x$ is the distance $(0.5 \mathrm{~cm})$ between the heater and either upstream or downstream thermocouple, and $v_{1}$ and $v_{2}$ are increases in the downstream and upstream temperatures (from initial average temperatures), respectively, $x \mathrm{~cm}$ from the heater. 
Table 1. Tree sizes and probe measurement depths.

\begin{tabular}{|c|c|c|c|c|c|}
\hline $\begin{array}{l}\text { Nkazana } \\
\text { Peat swamp } \\
\text { forest site }\end{array}$ & $\begin{array}{r}\text { Overbark } \\
\text { diameter } \\
(\mathrm{m})\end{array}$ & Bark & $\begin{array}{r}\text { Sapwood } \\
\text { depth } \\
(\mathrm{m})\end{array}$ & $\begin{array}{l}\text { Probe depths } \\
\text { below outer } \\
\text { bark surface }(\mathrm{m})\end{array}$ & $\begin{array}{r}\text { Tree height } \\
(\mathrm{m})\end{array}$ \\
\hline Syzygium cordatum & 0.430 & 0.008 & 0.055 & $\begin{array}{l}1=0.020,2=0.035 \\
3=0.040,4=0.060 \\
5=0.020,6=0.035 \\
7=0.040,8=0.060\end{array}$ & 22.5 \\
\hline Shirakiopsis elliptica & 0.081 & 0.003 & 0.033 & $\begin{array}{l}1=0.006,2=0.012 \\
3=0.020,4=0.030\end{array}$ & 6.8 \\
\hline \multicolumn{6}{|l|}{ Dune forest site } \\
\hline Drypetes natalensis & 0.069 & 0.002 & 0.030 & $\begin{array}{l}1=0.005,2=0.010 \\
3=0.015,4=0.025\end{array}$ & 4.5 \\
\hline Eugenia natalitia & 0.132 & 0.002 & 0.047 & $\begin{array}{l}1=0.010,2=0.020 \\
3=0.030,4=0.045\end{array}$ & 7.5 \\
\hline Mimusops caffra & 0.161 & 0.005 & 0.060 & $\begin{array}{l}1=0.010,2=0.020 \\
3=0.030,4=0.045\end{array}$ & 7.2 \\
\hline
\end{tabular}

A thermal diffusivity $(k)$ of $2.5 \times 10^{-3} \mathrm{~cm}^{2} \mathrm{~s}^{-1}$ (Marshall, 1958) was used.

Probes were inserted into trees with single stems and at a height of between $0.5 \mathrm{~m}$ and $1.4 \mathrm{~m}$ above the ground and below any branches. A drill guide was strapped firmly to the stem to ensure that holes were drilled with the correct spacing and parallel alignment. However, slight misalignment was assessed by checking for inconsistencies in the zero flux values. This was done by examining periods during which zero sap flow $\left(V_{\mathrm{h}}=0\right)$ was most likely to occur - such as predawn, rainfall periods, high relative humidity and low soil moisture periods. The $V_{\mathrm{h}}$ values at these times may subsequently be adjusted to zero, and the average of these adjustments provided the offset value applied to the whole data set. For all probe pairs, the offset was $<5 \%$ of the midday sap flow rates.

Wounding or non-functional xylem around the TCs (Table 2) was accounted for using wound correction coefficients described by Swanson and Whitfield (1981). Sap velocities were then calculated by accounting for wood density and sapwood moisture content (Table 2) as described by (Marshall, 1958). Finally, sap velocities were converted to tree water use or sap flow $\left(\mathrm{Lh}^{-1}\right)$ by calculating the sum of the products of sap velocity and cross-sectional area for individual tree stem annuli (determined by below-bark individual probe insertion depths and sapwood depth). In this way, point measurements of sap velocity were weighted according to the amount of conducting sapwood they represent in the annulus.

Stem diameters were monitored at the probe installation height of the tree trunk at monthly intervals to determine sapwood area. A corer was used to determine the interfaces between the bark, sapwood and heartwood (Table 1). These were distinguished by colour, wood hardness and in some
Table 2. Tree specific data required for calculation of sap flow.

\begin{tabular}{lrrr}
\hline $\begin{array}{l}\text { Peat Swamp } \\
\text { Forest site }\end{array}$ & $\begin{array}{r}\text { Wood density } \\
\left(\mathrm{m}^{3} \mathrm{~kg}^{-1}\right)\end{array}$ & $\begin{array}{r}\text { Moisture } \\
\text { fraction }\end{array}$ & $\begin{array}{r}\text { Average } \\
\text { wounding }(\mathrm{mm})\end{array}$ \\
\hline $\begin{array}{l}\text { Syzygium cordatum } \\
\text { Shirakiopsis elliptica }\end{array}$ & 0.56 & 0.83 & 3.4 \\
\hline Dune Forest site & 0.53 & 0.73 & 3.7 \\
\hline Drypetes natalensis & & & \\
Eugenia natalitia & 0.54 & 0.89 & 3.2 \\
Mimusops caffra & 0.73 & 0.47 & 3.2 \\
\hline
\end{tabular}

cases Methyl Orange was used to identify tyloses (Blanche et al., 1984). Tree height was also measured monthly using a tree height rod at the DF and hypsometer (VL402, Haglöf, Sweden) at the PSF. The LAI was measured (LAI 2200, LICOR Inc., Lincoln, Nebraska, USA) at monthly intervals at both sites. The measurement sequence of an above canopy, four below canopy and an above canopy reading were performed at each site in triplicate. However, due to the dense ferns at the PSF, the LAI of the ferns and trees was measured separately to the LAI of only the trees by measuring above the ferns.

Soil profile water content at both sites was measured (CR1000, Campbell Scientific Inc., Logan, Utah, USA) every hour to be in sync with the sap flow measurements. A time domain reflectometry system (TDR100, Campbell Scientific Inc., Logan, Utah, USA) with multiplexer (SDMX50, Campbell Scientific Inc., Logan, Utah, USA) and probes with three waveguides (CS605, Campbell Scientific Inc., Logan, Utah, USA) were installed at depths of $0.025 \mathrm{~m}, 0.075 \mathrm{~m}$, $0.125 \mathrm{~m}, 0.250 \mathrm{~m}, 0.500 \mathrm{~m}$ and $1.000 \mathrm{~m}$. The determination 
of volumetric water content by time domain reflectometry (TDR) has been well established by Topp et al. (1980) and Ledieu et al. (1986). The linear Ledieu conversion coefficients were used to convert the apparent probe length (measured by the TDR100) over the real probe length (known) to volumetric water content. Probe cable lengths were kept to a minimum to avoid distortion of the waveform caused by cable (RG58) impedance. The soils do not have high electro-conductivities which can cause signal attenuation due to ionic conduction and were therefore suitable for measurement with TDR methodology.

At the DF site, soil water potential sensors (Model 253, Irrometer Company, Riverside, California, USA) were installed with the CS605 sensors. The data was also recorded hourly using the same logger described above but a multiplexer (Am16/32, Campbell Scientific Inc., Logan, Utah, USA) was used to extend the number of measurement channels. These sensors were included at the DF due to the dry nature of the soils and a hypothesis that water was likely to be a limiting factor at this site. The soil water potential against which the trees extract water was therefore of interest at the drier site. At the PSF site, the water table was close to the surface $(0.5-1.0 \mathrm{~m})$ and it was unlikely that water would be a limiting factor and therefore water potentials would be permanently low.

The watermark sensors used to measure water potential at the DF site have a range of 0 to $125 \mathrm{kPa}$ beyond which the linear calibration has not been verified (Thompson and Armstrong, 1987). Unfortunately, the conditions at the DF were drier than expected and frequently out of this range. Therefore, the water retention characteristics of the soils were determined for the PSF and DF sites using undisturbed cores analysed in the laboratory at pressures between 0 and $-1500 \mathrm{kPa}$ following the methods and procedures of Klute and Dirksen (1986). Particle size distribution was also determined in the laboratory using the methods described by Gee and Bauder (1986).

The groundwater level (Solinst levelogger 3001, Ontario, Canada) at the PSF was measured at hourly intervals to coincide with the sap flow measurements. A perforated PVC access tube, lined with a geotextile was installed at the site for the monitoring of groundwater levels to approximately $1.8 \mathrm{~m}$. The DF groundwater level was measured (Solinst levelogger, Ontario, Canada) approximately $3 \mathrm{~km}$ to the north $\left(28^{\circ} 10.407^{\prime} \mathrm{S}, 32^{\circ} 32.115^{\prime} \mathrm{E}\right)$ near the top of the dunes, also at hourly intervals in a steel cased borehole.

Soil samples were collected (approximately $2 \mathrm{~kg}$ per sample) for the determination of root distribution at each site using a Eijkelkamp Edelman Extendible Auger for sand. Samples were collected from three different locations around the sites from soil pits. The samples were oven dried $\left(105^{\circ} \mathrm{C}\right)$ and weighed. The roots were separated from the soil with a $0.002 \mathrm{~m}$ sieve, oven dried and weighed again to determine the mass of roots per mass of dry soil. All root sizes were included in the measurement, which at the PSF included tree
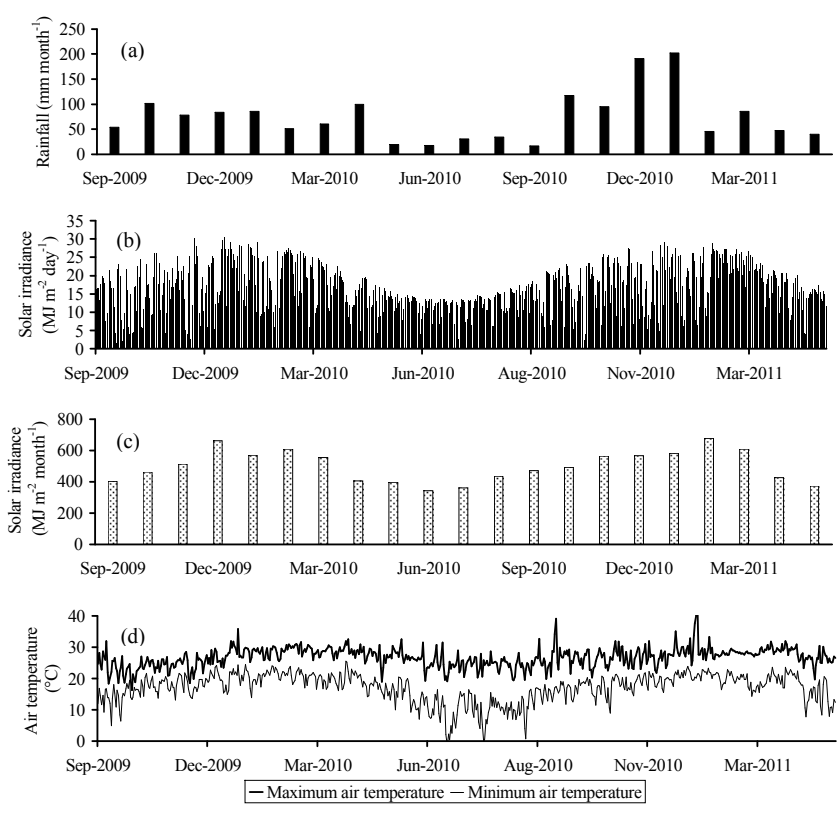

Fig. 3. The (a) monthly rainfall, (b) daily solar radiant density, (c) monthly solar radiant density, and (d) daily maximum and minimum air temperatures at the Mfabeni Mire.

and fern roots. At the DF, only trees were present as there was very little undergrowth around the measurement site.

\section{Results}

\subsection{Weather conditions during the study period}

The annual precipitation measured over the 2009-2010 hydrological year (October 2009 to September 2010) was $650 \mathrm{~mm}$, well below the long-term average of $1200 \mathrm{~mm} \mathrm{yr}^{-1}$. The summer rainfall over the 2009-2010 period was particularly low $(424 \mathrm{~mm})$, contributing to the dry conditions. The 2010 winter rainfall was characteristically low but was augmented by frontal conditions in July and August providing 30 and $34 \mathrm{~mm} \mathrm{month}^{-1}$ of rainfall, respectively (Fig. 3a). The summer rains of $2010-2011$ improved $(735 \mathrm{~mm})$ and were evident from October onwards, with December and January experiencing 191 and $202 \mathrm{mmmonth}^{-1}$, respectively, compared with 84 and $85 \mathrm{mmmonth}^{-1}$ in the previous year (Fig. 3a). The long-term summer average at the nearby South African Weather Services station $(0339756 \mathrm{~W})$ was $738 \mathrm{~mm}$ (Kunz, 2004; Lynch, 2004) showing that the 2009-2010 summer was drier and the 2010-2011 summer close to the long-term summer average rainfall.

Daily solar radiant density was seasonal, peaking at $30 \mathrm{MJ} \mathrm{m}^{-2}$ in summer and $12 \mathrm{MJ} \mathrm{m}^{-2}$ in winter on clear days (Fig. 3b). The daily solar radiant density was more variable in summer due to cloud cover, which was particularly prevalent during the mornings until 11:00 LT. This cloud cover 


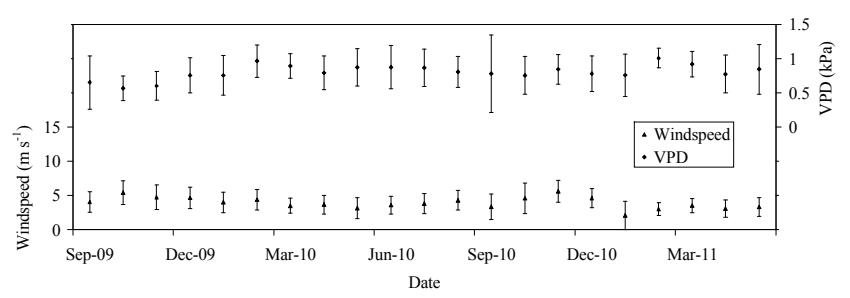

Fig. 4. Monthly average vapour pressure deficit and wind speed with standard deviation error bars measured at the Mfabeni Mire during daylight hours.

effect during summer is clear from the differences in the year on year monthly solar radiant densities (Fig. 3c). During the summer of 2009-2010, December (661 MJ) had the highest solar radiant density, whereas in 2010-2011 February (676 MJ) had the highest. This variability in cloud cover, which is able to influence monthly solar radiation totals in summer, is important to note as tree sap flow response to energy is well documented (Landsberg and Waring, 1997; Meiresonne et al., 1999; Granier et al., 2001; Williams et al., 2001; Wullschleger et al., 2001; Meinzer et al., 2004).

The warm Mozambique Current from the north exerts a warming influence on the coastal areas. Temperatures are warm to hot in summer with maximums frequently above $30^{\circ} \mathrm{C}$ (Fig. 3d). Winter months are mild to warm and maximum temperatures were generally around $25^{\circ} \mathrm{C}$. The average daily minimum temperatures were around $20^{\circ} \mathrm{C}$ in summer and rarely below $5^{\circ} \mathrm{C}$ in winter, although on $17 \mathrm{June} 2010$ the temperature dropped to $-1.2{ }^{\circ} \mathrm{C}$ indicating frost conditions, which are considered extremely rare in the area (Meadows, 1985).

The humid and subtropical coastal conditions over the period of measurement are best described by the average daytime $\left(R_{n}>0\right)$ VPD of $0.80 \mathrm{kPa}$ (Fig. 4), which is low, indicating a low atmospheric evaporative demand generally. The monthly average VPD was lowest in October and highest in February during both 2010 and 2011. The daytime standard deviations were mostly below $0.30 \mathrm{kPa}$ except in September when the standard deviation of the VPD was $>0.38$ during both 2010 and 2011.

The wind in the research area was seasonal with the highest monthly average wind speeds experienced in October to December and the lower wind speeds in winter (April to July). The average daytime $\left(R_{n}>0\right)$ wind speed was $3.9 \mathrm{~m} \mathrm{~s}^{-1}$ over the measurement period (Fig. 4). The highest monthly average was measured in October $\left(5.4 \mathrm{~m} \mathrm{~s}^{-1}\right)$ and the lowest in May $\left(3.2 \mathrm{~m} \mathrm{~s}^{-1}\right)$.

\subsection{Soil profile and water content}

A surface organic horizon (peat) at the PSF site was approximately $0.3 \mathrm{~m}$ deep and the roots were concentrated in this horizon (Table 3). There was a sharp transition below the
Table 3. Dry root mass per unit volume of soil along a $1.0 \mathrm{~m}$ soil profile at the peat swamp forest and dune forest sites.

\begin{tabular}{rrr}
\hline Depth & $\begin{array}{r}\text { Dune } \\
\text { forest site } \\
\left(\mathrm{g} \mathrm{m}^{-3}\right)\end{array}$ & $\begin{array}{r}\text { Peat swamp } \\
\text { forest site } \\
\left(\mathrm{g} \mathrm{m}^{-3}\right)\end{array}$ \\
\hline 0.005 & 18.7 & 7.5 \\
0.250 & 2.6 & 1.3 \\
0.500 & 0.3 & 1.2 \\
1.000 & 0.1 & 0.6 \\
\hline
\end{tabular}

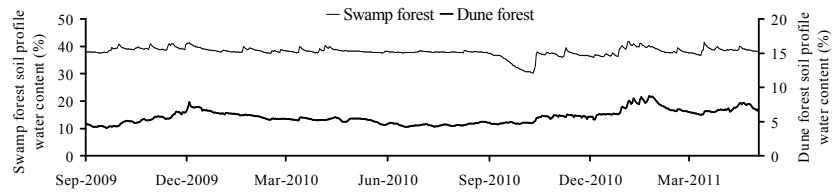

Fig. 5. Total volumetric water content in the upper $1.5 \mathrm{~m}$ of the soil profile at the dune forest and peat swamp forest sites.

organic horizon to a coarse (11\%), medium (36\%) and fine (42\%) sand profile (by mass - the remainder being silt and clay) that contained less root material but with some roots extending below $1 \mathrm{~m}$. The volumetric water content $(\theta)$ was generally high at the PSF site. The incremental measurements down the profile (data not shown) indicated that the profile was drier near the surface (15 to $20 \%$ ) and wetter at depth (40 to $50 \%$ ). At $0.5 \mathrm{~m}, \theta$ only responded to rainfall events over $15 \mathrm{~mm}$ (over a few h) while at $1.0 \mathrm{~m}, \theta$ remained unchanged between September 2009 and August 2010, when the water table was above the soil water measurement probe. From the beginning of September 2010 to mid-October 2010, $\theta$ dropped $17 \%$ from $39 \%$ to $22 \%$ indicating that the water table had moved below the probe at $1 \mathrm{~m}$. Following spring rains (117 $\mathrm{mm}$ in October 2010), $\theta$ increased first rapidly and later more slowly for the remainder of the measurement period to levels $(38 \%)$ close to previous values $(39 \%)$. After rainfall, the surface drained rapidly indicating low water retention, characteristic of sandy soils. The total soil profile volumetric water content $\left(\theta_{\mathrm{PT}}\right)$ at the PSF site fluctuated between $30 \%$ and $42 \%$ over the $1.5 \mathrm{~m}$ depth profile (Fig. 5). Despite the differences in the PSF site water retention characteristic down the soil profile (Fig. 6a), it was clear that the $-1500 \mathrm{kPa}$ wilting points $(10 \%$ at $0.8 \mathrm{~m}$, and $30 \%$ at $0.4 \mathrm{~m})$ were both below the driest limits reached in $\theta_{\mathrm{PT}}(30 \%)$. This indicated that soil water was not a limit to tree water use, particularly considering that the water table level was generally between $0.5 \mathrm{~m}$ and $1.0 \mathrm{~m}$. Rainfall interception was likely to have been relatively high (due to the high LAI) but was unlikely to have been an important process in terms of limiting water use as the vegetation had constant access to water at this site.

At the DF site, there was a high root density near the surface (Table 3 ) that decreased ( $8 \%$ to $1 \%$ root mass per soil 

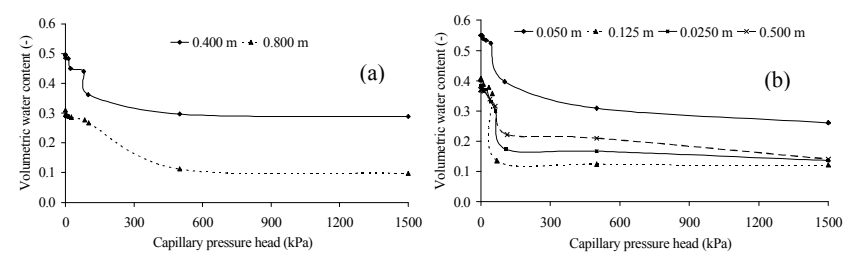

Fig. 6. Water retention characteristics of the (a) peat swamp forest and (b) dune forest sites.

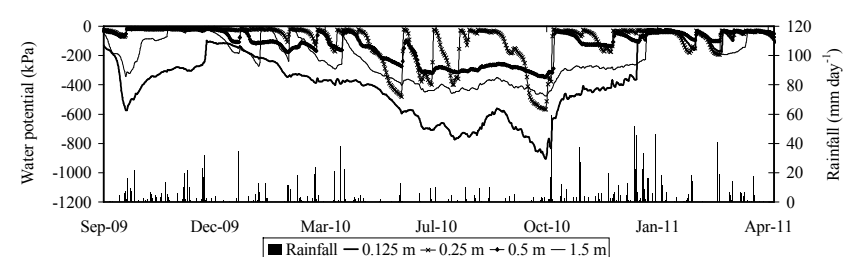

Fig. 7. Water potential and daily rainfall measured at the dune forest site.

mass) from $0.1 \mathrm{~m}$ to $0.2 \mathrm{~m}$. The surface sands were water repellant as determined by the Water Drop Penetration Time test, as described by Dekker et al. (2001). The soil texture did not change down the profile and was mainly medium $(46 \%)$ and fine $(45 \%)$ sands (0 to $0.350 \mathrm{~m})$. Rainfall interception was likely to have been an important process at the DF as only rainfall events (over a few h) $>10 \mathrm{~mm}$ (or rainfall on consecutive days) affected the upper soil water profile (0 to $0.125 \mathrm{~m})$. Smaller rainfall events $(<4 \mathrm{~mm})$ during the beginning of December 2009 had no impact on the surface $\theta$. In some cases, rainfall events of approximately $10 \mathrm{~mm}$ (over a few $\mathrm{h}$ ) resulted in small changes in surface $\theta$, yet large changes in soil water potential. For example, from May 2010 to July 2010, $\theta$ at $0.075 \mathrm{~m}$ decreased from $8 \%$ to $7 \%$ (data not shown) whereas the measured water potential decreased from $-400 \mathrm{kPa}$ to $-700 \mathrm{kPa}$ (Fig. 7). This was supported by the water retention characteristics, which showed that the sands drained rapidly beyond $-400 \mathrm{kPa}$ and that small changes in $\theta$ caused large changes in water potential. The $\theta_{\mathrm{PT}}$ ranged from $5 \%$ to $10 \%$ but the wilting point $(-1500 \mathrm{kPa})$ of the sands was between 12 and $14 \%$ (Fig. 6b). The profile, or at least large parts of the profile, were outside the plant available water range $(0$ to $-1500 \mathrm{kPa})$ for extended periods and water availability was certain to have limited tree water use of the DF site.

The dry conditions at the DF site were frequently beyond the accurate operating range of the watermark sensors $(-125 \mathrm{kPa})$. However, the data do serve to show the relatively dry conditions in the main rooting area of the profile ( 0 to $0.125 \mathrm{~m}$ ). At $0.25 \mathrm{~m}$ the soil water potential fluctuated rapidly but the water potential was generally lower (less negative) than at $0.125 \mathrm{~m}$. At $0.5 \mathrm{~m}$ and $1.5 \mathrm{~m}$ the water potential fluctuated less but there was an increasing trend (more negative)

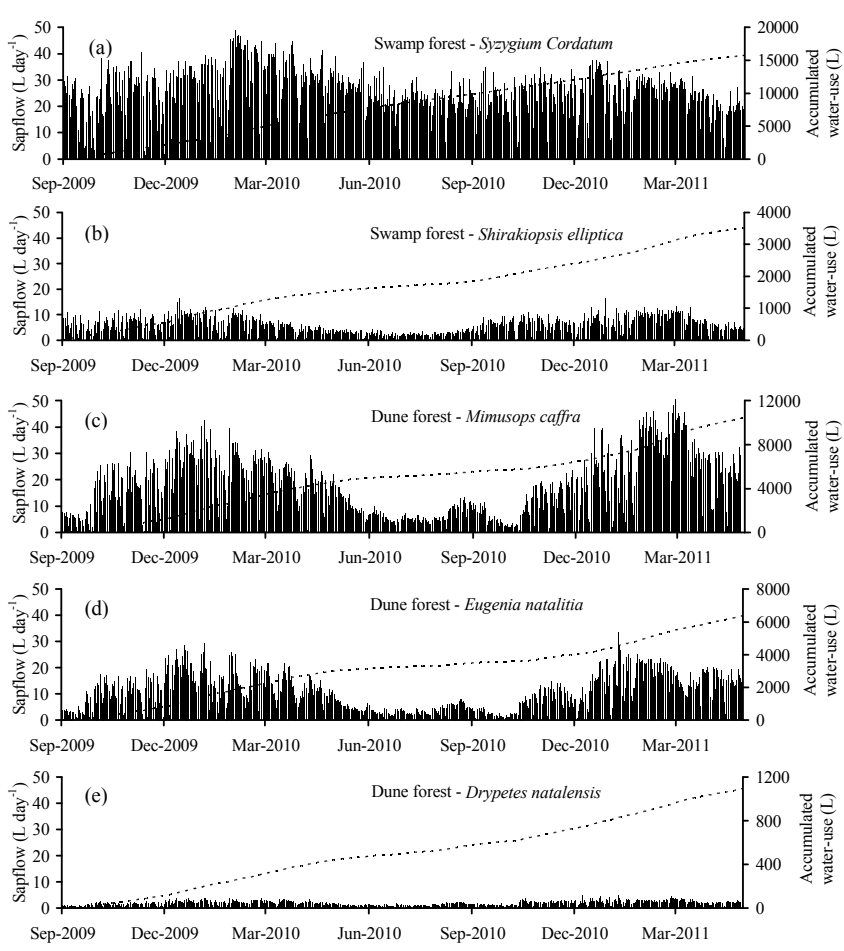

Fig. 8. Daily water use (bars) and accumulated water use (dashed line) over 20 months of the peat swamp forest trees (a) Syzygium cordatum (b) Shirakiopsis elliptica and dune forest trees (c) Mimusops caffra, (d) Eugenia natalitia and (e) Drypetes natalensis.

in water potential with depth indicating that the profile became drier with depth beyond $0.25 \mathrm{~m}$.

\subsection{Tree water use}

At the PSF site, the maximum water use of the evergreen, overstory tree (Syzygium cordatum) ranged from approximately $30 \mathrm{Ld}^{-1}$ in winter to $45 \mathrm{Ld}^{-1}$ in summer. The total water use of the measurement period (20 months) was $15800 \mathrm{~L}$ and the accumulated water-use line has a constant gradient indicating a relatively constant water use throughout the year (Fig. 8a). Of the two summer seasons observed (October to March 2009-2010 and 2010-2011), the water use was $16 \%$ higher in the first summer $(5402 \mathrm{~L}$ vs. $4643 \mathrm{~L}$ ). The first summer was drier with a rainfall of only $424 \mathrm{~mm}$ vs. $735 \mathrm{~mm}$ in the following year. However, the wetter year was no more cloudy and the difference in total solar irradiance between the two summer seasons was within $4 \%$ (3367 MJ vs. $3488 \mathrm{MJ}$ ), the average daily VPD was similar $(\sim 0.8 \mathrm{kPa})$ and the total accumulated reference evaporation $\left(\mathrm{ET}_{\mathrm{r}}\right) 583 \mathrm{~mm}$ versus $601 \mathrm{~mm}$ in $2009-2010$ and 2010-2011, respectively. The difference in water use between the two summer periods therefore remains unexplained based on adequate soil water availability and similar atmospheric demands. The mid-canopy tree (Shirakiopsis elliptica) was a smaller, semi-deciduous tree. The water 

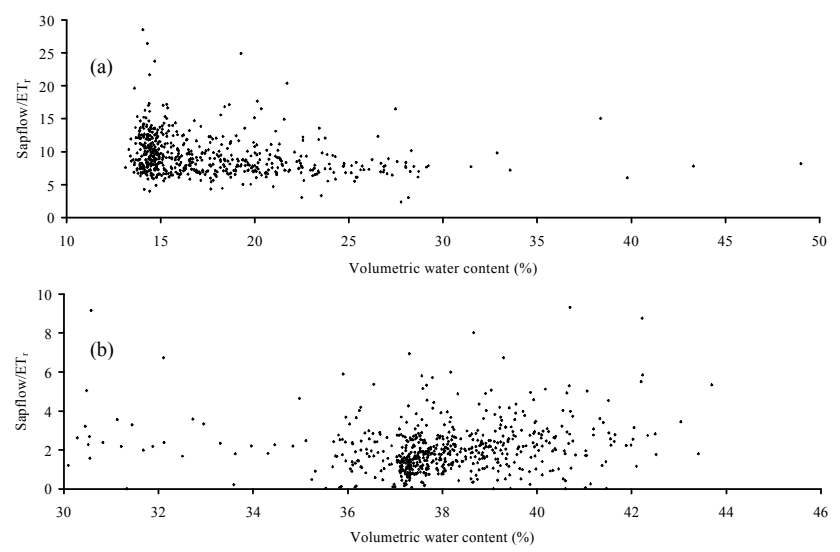

Fig. 9. The ratio of sap flow to reference evaporation versus the soil water content $(0.075 \mathrm{~m})$ at the peat swamp forest site for (a) Syzygium cordatum and (b) Shirakiopsis elliptica.

use was distinctly seasonal $\left(2 \mathrm{Ld}^{-1}\right.$ in winter and $12 \mathrm{Ld}^{-1}$ in summer) as shown by the s-shape of the accumulated water-use line which totaled $3500 \mathrm{~L}$ over the measurement period (20 months). The shaded mid-canopy tree therefore used about $75 \%$ less water than the overstory tree. In contrast to the overstory tree, the mid-canopy tree water use was $8 \%$ higher in the wetter summer of 2010-2011 (1264 L vs. $1361 \mathrm{~L})$.

The three evergreen DF trees (Fig. 8c to e) exhibited similar seasonal patterns and a regression of sap flow between the mid-canopy and overstory trees (Eugenia natalitia versus Mimusops caffra) indicated a similar response in sap flow at a daily level $\left(R^{2}=0.81\right)$. The linear relationship between a mid-canopy tree (Eugenia natalitia) and the smaller understory tree (Drypetes natalensis) was not as good $\left(R^{2}=0.71\right)$ indicating a difference in water-use dynamics due to rooting depth or understory versus overstory light or VPD conditions. The total water use of the overstory tree Mimusops caffra and mid-canopy Eugenia natalitia was $10400 \mathrm{~L}$ and $6400 \mathrm{~L}$, respectively, while the understory tree water use was the lowest at $1100 \mathrm{~L}$.

For all three DF trees, summer transpiration was higher than in winter (shown by the s-shaped accumulated water use in Fig. 8c-e), yet within the summer season there was daily variation due to cloud and rain. The daily water use was highest for the emergent Mimusops caffra (5 to $45 \mathrm{Ld}^{-1}$ ), whereas for the Eugenia natalitia and Drypetes natalensis daily water use was lower ( 2 to $28 \mathrm{Ld}^{-1}$ and 1 to $4 \mathrm{Ld}^{-1}$ ). The summer (October to March) water use of the emergent Mimusops caffra was $3924 \mathrm{~L}$ during the drier summer of 2009-2010 and 4057 L in the wetter summer of 2010-2011. The understory Drypetes natalensis displayed the same pattern with a lower water use $(362 \mathrm{~L})$ in the drier summer of 2009-2010 and higher water use $(423 \mathrm{~L})$ in the wetter summer of 2010-2011.
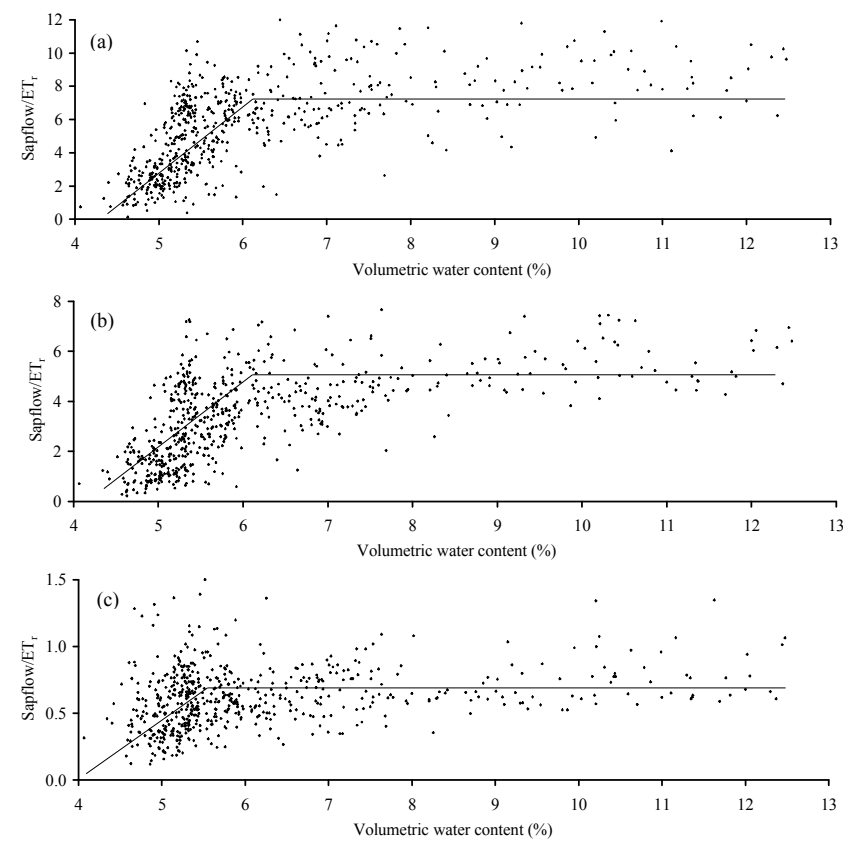

Fig. 10. The ratio of sap flow to reference evaporation versus the soil water content $(0.075 \mathrm{~m})$ at the Dune Forest site for (a) Mimusops caffra, (b) Eugenia natalitia and (c) Drypetes natalensis with the solid line representing the split-line regression.

The dependence of DF transpiration on soil water availability was clear from the increase in observed transpiration from all three trees (Mimusops caffra: 3.8 to $13.7 \mathrm{Ld}^{-1}, E u$ genia natalitia: 1.8 to $7.9 \mathrm{Ld}^{-1}$ and Drypetes natalensis: 0.8 to $2.4 \mathrm{Ld}^{-1}$ ) between 13 August and 15 September 2010, following $45 \mathrm{~mm}$ of rainfall in the previous few weeks. This corresponded to a positive response in the soil water potential near the surface $(0.125 \mathrm{~m})$ from 8 August (Fig. 7) from -800 to $-550 \mathrm{kPa}$. Following the increase in transpiration, the upper soil profile water potential increased again rapidly from $-550 \mathrm{kPa}$ (at $0.125 \mathrm{~m}$ ) to drier levels of $-900 \mathrm{kPa}$ (Fig. 7) with a concomitant decrease in transpiration until the seasonal spring rains arrived in October 2010.

In terms of climatic indicators of sap flow, the linear regressions of sap flow with climatic variables were generally poor. For example, VPD and solar radiation separately accounted for $22 \%$ and $47 \%$, respectively, of the variation in emergent Mimusops caffra sap flow in the DF. At the PSF site, VPD and solar radiation accounted for $42 \%$ and $47 \%$, respectively, of the variation in the sap flow of the Syzygium cordatum.

A split-line regression (also known as continuous twophase regression or breakpoint regression) is used to describe abrupt changes in the relationship between physiological responses and environmental parameters that cannot be described by a single regression equation (Perry, 1982). In Figs. 9 and 10, a split-line regression using Genstat software (VSN International, 2011) was applied to determine whether 
changes in the ratio (unitless) of tree water use to FAO-56 reference evaporation $\left(\mathrm{ET}_{\mathrm{r}}\right)$ were related to $\theta$ at a depth of $0.075\left(\theta_{7.5}\right)$, where the highest root concentration existed at both sites. A single significant regression would indicate a constant relationship between tree water use over $\mathrm{ET}_{\mathrm{r}}$ against $\theta_{7.5}$ and would suggest that as $\mathrm{ET}_{\mathrm{r}}$ increases (atmospheric demand), tree water use increases with no limit imposed by $\theta_{7.5}$ or that $\theta_{7.5}$ continuously imposes a constant limit on tree water use. However, a split line regression would indicate that $\mathrm{ET}_{\mathrm{r}}$ over tree water use is dependent on $\theta_{7.5}$ over a range but reaches a $\theta_{7.5}$ beyond which it is independent - the breakpoint. At the PSF site, there was no indication of a $\theta_{7.5}$ limit imposed on water use (Fig. 9a and b). The $\theta_{7.5}$ was mostly between $36 \%$ and $42 \%$, but drier at times, reaching $30 \%$; yet, the ratio of water-use to atmospheric demand remained $>5$ (Fig. 9a and b). However, at the DF site, the split-line regressions (Fig. 10a to c) indicated that $\theta_{7.5}$ imposed a severe constraint on tree water use. On days when the profile water content was below a breakpoint value, there was a concomitant decrease in the ratio of water use to $\mathrm{ET}_{\mathrm{r}}$ indicating a two stage relationship. The understory Drypetes natalensis $\theta_{7.5}$ breakpoint was $5.6 \%$ while the overstory Eugenia natalitia and Mimusops caffra were $6.2 \%$ and $6.1 \%$, respectively. The soil water was a limit for $53 \%$ (Drypetes natalensis), $68 \%$ (Eugenia natalitia) and $70 \%$ (Mimusops caffra) of the measurement period.

\section{Discussion}

There are no comparisons of water use for either forest type in the research literature. In South Africa, the focus of DF research has primarily been rehabilitation following mining, which has been widespread on the east coast of South Africa (van Aarde et al., 1996; Ruiz-Jaen and Mitchell Aide, 2005; Grainger and van Aarde, 2012). Dune forest biodiversity (Wassenaar et al., 2005) as well as water use and the spread of some dune pioneer species including the shrub Scaevola plumieri and exotic grass Ammophila arenaria have been studied (Peter, 2000; Peter and Ripley, 2000; Peter et al., 2003; Ripley and Pammenter, 2004).

Furthermore, PSF research in general is limited internationally. Much of the existing tropical peat swamp forest research stems from South East Asia (Anderson et al., 1983; Rieley and Ahmed-Shah, 1996). Internationally, existing subjects include, amongst others, fires (Page et al., 2002; Grundling and Grobler, 2005), species composition studies (Wessels, 1997; Venter, 2003; Grobler, 2009), carbon flux measurements (Jauhiainen, et al., 2005) and cultivation (Grobler et al., 2004). Oren et al. (1999) provided information on transpiration rates of Taxodium distichum trees flooded in an artificial impoundment; however, this swamp Cyprus, found in Carolina in the USA, is deciduous and has needle like leaves that are very different in structure to the PSF trees of Maputaland. Some tropical forest research may be applicable to the PSF's of Maputaland, but in terms of water use, it would be unreliable to use existing tree wateruse data from other countries due to differences in vegetation structure, soil types and weather patterns. These results are therefore unique internationally and will provide the basis for further studies and modelling.

Page et al. (1999) state that tropical peat swamp forest ecosystems have until recently received little attention as they fall between the two disciplines of peatland ecology and forest ecology. However, with the increased awareness of the carbon stored in peatlands and the recognition of their role in the global environmental change process, there has been a renewed interest in peatlands. Yet, despite an understanding of the influence of droughts and water levels on carbon releases from peatlands (Suzuki et al., 1999; Hirano et al., 2007; Wösten at el., 2008), together with impending climate change, there remains little understanding of their vegetative water use. This research therefore fills an important gap in our understanding of PSFs vegetation. It provides some of the first results of individual tree water use within a PSF as well as the contrasting water use from trees in a nearby DF and expands on the differences in the water-use dynamics between the two forest types.

The proximity of the two sites $(4 \mathrm{~km})$ and the similar climatic conditions experienced, allowed a comparison of water use from two types of indigenous forest and showed the importance of landscape position and site-specific conditions such as soil water content profile. From the soil water data, it was clear that the roots of the PSF trees have permanent access to soil water, whereas the DF tree roots only have access to soil water following rainfall that was temporarily stored in the soil profile. Although large rainfall events $\left(>20 \mathrm{mmd}^{-1}\right)$ recharged the soil profile at depths of up to $1.5 \mathrm{~m}$ at the DF site, many rainfall events were $<10 \mathrm{~mm}$ (over a few h) and only recharged the shallow profile (0 to $0.125 \mathrm{~m}$ ) where there was a high root density (Table 3 ). Relatively small changes in volumetric water content translated into larger changes in water potential due to the sandy texture of the profile at the DF. For example, from May 2010 to July 2010 , a drop in $\theta$ of $1 \%$ corresponded to a $300 \mathrm{kPa}$ decrease in water potential. However, during relatively small rain events ( $>4 \mathrm{~mm}$, but $<10 \mathrm{~mm}$ over a few $\mathrm{h}$ ) the soil water potential increased (less negative) and the tree water use increased correspondingly, as evidenced between 13 August and 15 September 2010 (Fig. 8c to e). This adaptation of the trees to dune locations allows the trees to survive extended dry periods by opportunistically utilising water coming from the numerous smaller rainfall events that only wet the shallow soil profile.

In the water limited environment of the dune forest, interception was important and it was found that rainfall events $<4 \mathrm{~mm}$ within a few $\mathrm{h}$ had no impact on the surface $\theta$ or water potential if the antecedent conditions were dry. Research by Bulcock and Jewitt (2012) also found that in precipitation events of $4 \mathrm{~mm}$ or less, $100 \%$ interception commonly 
occurred in forest interception studies depending on antecedent conditions of the leaf litter and canopy. The variable weather conditions and the type of rainfall experienced have an effect on $\theta$ and therefore the water availability and DF water use.

The complexity of soil water in dune sands was studied by Ritsema and Dekker (1994), who found that the pattern of soil water was irregular in dune sands. Due to a steep relationship between hydraulic conductivity and $\theta$ in the dry range, small changes in $\theta$ gave rise to large changes in hydraulic conductivity. These differences in hydraulic conductivity together with the water repellency of the surface sands, induced soil water variability and preferential flow paths. Similar processes are likely in the dune sands of Maputaland, which explains some of the irregularities observed in the soil water potential results down the profile, such as the rapid fluctuations at $0.25 \mathrm{~m}$ but not above that level in the profile. The relatively large changes in hydraulic conductivity and soil water potential brought about through small changes in $\theta$ means that plant water availability changes rapidly. This emphasises the importance of the tree adaption to respond quickly to changes in soil water conditions but also warns of single site measurements to characterise the soil water regime of dunes.

Tree water use was clearly not limited by soil water availability at the PSF site. The limits to transpiration of the overstory tree were primarily radiation (due to prevailing cloud) and VPD. At the DF however, soil water was found to play a dominant role in limiting water use (Fig. 10a to c). Due to the variable climate and well-documented droughts in the area, this limitation was frequently imposed and affected the water use of all three DF trees. Existing evaporation models such as the Priestley-Taylor and Penman-Montieth that are meteorologically driven with moderating functions built on physiological controls may provide good results for the estimation of PSF water use, but are not suitable in applications such as the DF. At the DF, supply was critical and detailed meteorological measurement and calculation of atmospheric demand are likely to be largely irrelevant for a large proportion of the time. Calder (1998) suggested that evaporation could be interpreted in terms of six types of controls and limits on the evaporation process depending on climate, namely: advection, solar radiation, raindrop size (influences interception evaporation), soil water, tree size and physiology. The PSF and DF sites are, however, only $4 \mathrm{~km}$ apart and rather than separating the controls based on climatic areas in the Eastern Shores; it would be most appropriate to consider landscape position. The work by Calder (1998) was an important conceptual step towards understanding limits and constraints to evaporation but was limited to homogenous vegetation stands and does not explain the complexity and heterogeneity of indigenous vegetation types and different landscape positions.

The seasonal water use at the DF site was dependent on the rainfall, which in turn created a limit, imposed on water use by soil water availability. It is logical that the tree water use at the DF site was therefore higher during the wetter summer of 2010-2011, when more soil water was available. However, at the PSF site, the summer water use of the overstory tree was higher during the drier summer (2009-2010) by $16 \%$. It was shown that soil water did not limit the tree water use and it therefore seems a reasonable result if climatic parameters supported a higher transpiration. However, this was not supported by the solar radiation, VPD or atmospheric demand $\left(E T_{r}\right)$ which indicated little difference in the year on year results.

Modelling water use using a two stage model is a concept understood by scientists in the past. Ritchie (1972) used a two stage model to estimate soil evaporation, differentiating between an energy limited constant stage and a second stage where the soil evaporation is limited by the hydraulic properties of the soil. Federer (1979) found that simple functions of volumetric water content could be used to determine the reductions in tree water use due to a soil water limitation. More recently this has been included in the FAO-56 reference evaporation and crop coefficient model as a soil evaporation reduction coefficient and to the reduction in crop transpiration as a water stress coefficient. The water-use and soil water results for the DF site indicated that this type of two stage model, for growth or water use, would have been applicable up to $70 \%$ of the time (for the Mimusops caffra) over the measurement period. However, the FAO-56 reference evaporation model has been developed for uniform canopies shorter than the DF and PSF canopies. Forest canopy water use has in the past been modelled using the Penman-Montieth formula together with a stomatal resistance model (Grip et al., 1989; Dolman et al., 1991). Results over longer periods (annual) have been reasonable but poor over shorter periods (less than a day). Roberts et al. (1993) used a multi-layer approach to solve the PenmanMontieth formula and measure canopy conductance at five canopy levels in an Amazonian forest. A simplification of the model using average values for the canopy were compared to measured transpiration and resulted in overestimates of up to $50 \%$.

Peat swamp forests and dune forests are under extreme pressure in South Africa (Grundling, 1998). Mining, agriculture, population expansion and poverty are amongst the major threats and to their existence. Peat swamp forests in particular, are targeted by informal community gardens due to fertile soils and water availability. Grundling and Grobler (2005) estimated that $60 \%$ to $80 \%$ of PSFs include crop species such as Musa paradisiaca (bananas), Colocasia esculenta (madumbes, also known as taros) and Ipomoea batatas (sweet potatoes). Governments are struggling to prioritise the flow of funding for the protection of these ecosystems (James et al., 2001). However, water neutral and water offset strategies are amongst the ideas and concepts to emerge that will sustainably provide finance for the protection of these critical ecosystems (Hoekstra, 2008). However, it is necessary to understand and quantify the water use of these 
indigenous ecosystems so that these offset strategies can be implemented. The water use of PSF and DF trees has until now been poorly understood and received little attention internationally. These results will therefore provide useful baseline information for further measurement and modelling studies.

\section{Conclusions and future research}

The two sites were in contrasting landscape positions but, due to their proximity, under similar climatic conditions. However, different limiting factors existed at the two sites, controlling water use at times. The soil water limitation at the DF site was clearly shown to reduce transpiration at the DF and not at the PSF, however, linear regression with climatic variables did not produce a good correlation at either site. Regression modelling of water use against multiple climatic variables and the soil water limits derived in this research forms the focus of a follow-up research paper. This will provide information on the controlling variables of water use to determine canopy conductance models for the PSF and DF. At the DF for example, when $\theta$ is not a limit then understanding the limits imposed by VPD or tree physiology for the overstory or VPD and solar irradiance for the understory trees are the next step towards providing a suitable model that can be used to estimate forest water use.

Both sites were dominated by shallow-rooted trees. The watertable was close to the surface during the measurements at the PSF site and only briefly went below $1 \mathrm{~m}$ at the end of the winter during an extended drought period. It is therefore not necessary for the trees to have deep roots to access water and a concentration of roots near the surface where nutrients are available is more effective. In contrast, the roots of the DF trees, on the 80 ma.s.l. high dunes, are not able to access the watertable and are therefore concentrated near the surface to optimise the uptake of through fall (Stone and Kalisz, 1991; Laclau et al., 2001). Rainfall events affected the soil water profile measurements at a depth of up to $1.5 \mathrm{~m}$ suggesting that groundwater recharge from the DF takes place but it is speculated that only extreme events ( 1 in $100 \mathrm{yr}$ ) such as the Demoina floods of 1984 are able to penetrate the deep sands of the dune.

The diversity of the vegetation and irregular spacing of the trees within the forests adds complexity to the possibility of up scaling the individual tree water use to forest community water use. It would be necessary to understand the relationships between tree water-use and tree height, stem diameter or canopy area to investigate the reliability of up scaling single tree water use. However, this still ignores soil evaporation and undergrowth water use and in terms of understanding the wider catchment hydrology it would therefore be beneficial to derive the ET of the PSF and DF using eddy covariance or scintillometry where appropriate. Analysis similar to those presented in this research, but with ET in place of individual tree water use (Figs. 9 and 10), would provide a useful indication of how effectively ET of the PSF and DF could be estimated from simple meteorological and soil water data. These ET results would provide the ET information typically used at catchment scales in hydrological modelling studies.

Within the DF in particular, the results presented were from a site at the dune crest. Water use may be different on lower slopes where the roots have access to groundwater. In addition, the orientation of the dunes along the coast results in east and west facing aspects. The DF trees facing the sea on the east are exposed to salt spray which may affect the process of transpiration (Sykes and Wilson, 1988; Robinson et al., 1998). According to Pooley (2003), the high winds and salt spray limit growth (and therefore water use) in the Maputaland DFs. Further research to investigate the occurrence of DF areas that potentially use groundwater on the lower slopes and the influence of slope position on transpiration would be beneficial particularly in terms of up scaling the water use of the DF from individual tree water-use results.

At the PSF, the dense Nephrolepis biserrata fern that covers the forest floor and the Stenochlaena tenuifolia (Blechnaceae) fern which grows up the tree stems had a higher leaf area than the tree canopy above, yet there is no information on their water-use dynamics. The ferns remained actively growing throughout the year and an understanding of their water use, including interception, would be critical to understand fully the long-term water use of the PSF as a whole.

The ecological and tourist value of the iSimangaliso Wetland Park have been acknowledged. In addition, the anthropogenic impacts were discussed as well as the susceptibility of the area to prolonged dry and wet periods. However, beyond the borders of the Park, the natural vegetation gives way to large areas of commercial forestry (mainly Eucalyptus) and sugarcane plantations. In terms of the current legislation in South Africa, forestry is a streamflow reduction activity, whereas sugarcane is not. Quantification of the water use of these commercial vegetation types is necessary to model the water balance of the wider catchment and determine more accurately the legislative allowance of streamflow reduction and the resulting impacts on blue and green water in the catchment.

Acknowledgements. The research presented in this paper was funded by the Water Research Commission (WRC) of South Africa in Key Strategic Area 2 (i.e. Water-Linked Ecosystems) and forms part of an unsolicited research project (Evapotranspiration from the Nkazana Swamp Forest and Mfabeni Mire). The iSimangaliso Wetland Park are acknowledged for their support in providing access to the research sites. Ab Grootjans, Piet-Louis Grundling and Althea Grundling were instrumental in initiating this work and sharing information. Assistance in the field by Siphiwe Mfeka, Alecia Nickless, Scott Ketcheson, David Clulow, Joshua Xaba and Lelethu Sinuka is much appreciated. The support provided by Erwin Sieben, Bikila Dullo and Mathilde Luïse was also invaluable.

Edited by: S. Uhlenbrook 


\section{References}

Allen, R. G., Pruitt, W. O., Wright, J. L., Howell, T. A., Ventura, F., Snyder, R., Itenfisu, D., Steduto, P., Berengena, J., Yrisarry, J. B., Smith, M., Pereira, L. S., Raes, D., Perrier, A., Alves, I., Walter, I., and Elliott, R.: A recommendation on standardized surface resistance for hourly calculation of reference ETo by the FAO56 Penman-Monteith method, Agr. Water Manage., 81, 1-22, 2006.

Anderson, J. A. R.: The tropical peat swamps of western Malesia, In Mire: swamp, bog, fen and moor, B. Regional studies, edited by: Gore, A. J. P., Amsterdam, Elsevier, 181-199, 1983.

Blanche, C. A., Nebeker, T. E., Schmitt, J. J., and Hodges, J. D.: Notes: Techniques for Distinguishing the Sapwood-Heartwood Boundary in Living Loblolly Pine (Pinus taeda L.), Forest Sci., 30, 756-760, 1984.

Boon, R.: Pooley's Tree of Eastern South Africa, A complete guide, Flora and Fauna Publications Trust, c/o Natal Herbarium, Botanic Gardens Road, Durban, South Africa, 2010.

Bosch, J. M. and Hewlett, J. D.: A review of catchment experiments to determine the effect of vegetation changes on water yield and evapotranspiration, J. Hydrol., 55, 3-23, 1982.

Bulcock, H. H. and Jewitt, G. P. W.: Field data collection and analysis of canopy and litter interception in commercial forest plantations in the KwaZulu-Natal Midlands, South Africa, Hydrol. Earth Syst. Sci., 16, 3717-3728, doi:10.5194/hess-16-37172012, 2012.

Burgess, S. O., Adams, M. A., Turner, N. C., Beverly, C. R., Ong, C. K., Khan, A. A. H., and Bleby, T. M.: An improved heat pulse method to measure low and reverse rates of sap flow in woody plants, Tree Physiol., 21, 589-598, 2001.

Calder, I. R.: Water-use by forests, limits and controls, Tree Physiol., 18, 625-631, 1998.

Calder, I. R.: The blue revolution: land use \& integrated water resources management, Earthscan Publications Ltd., London, United Kingdom, 1999.

Cyrus, D. P., Vivier, L., and Jerling, H. L.: Effect of hypersaline and low lake conditions on ecological functioning of St. Lucia estuarine system, South Africa: An overview 2002-2008, Estuar. Coast. Shelf S., 86, 535-542, 2010.

Dekker, L. W., Doerr, S. H., Oostindie, K., Ziogas, A. K., and Ritsema, C. J.: Water repellency and critical soil water content in a dune sand, Soil Sci. Soc. Am. J., 65, 1667-1674, 2001.

Dolman, A. J., Gash, J. H. C., Roberts, J., and Shuttleworth, W. J.: Stomatal and surface conductance of tropical rainforest, Agr. Forest Meteorol., 54, 303-318, 1991.

Dominy, G. A.: History of Lake St. Lucia Eastern Shores, in Environmental impact assessment, Eastern Shores of Lake St. Lucia, Kingsa/Tojan Lease Area, Reports on the Key Issues, 2, CSIR Environmental Services, Pretoria, South Africa, 1992.

DWAF: Stream Flow Reduction Allocations: History, Department of Water Affairs and Forestry, Pretoria, South Africa, available at: http://www.dwaf.gov.za/sfra/sfralichistory.asp (last access: 18 March 2004), 2004.

Dye, P. J.: Modelling growth and water use in four Pinus patula stands with the 3-PG process-based model, Southern African Forestry J., 191, 53-63, 2001.

Dye, P. J. and Versfeld, D.: Managing the hydrological impacts of South African plantation forests: An overview, Forest Ecol. Manag., 251, 121-128, 2007.
Dye, P. J., Gush, M. B., Everson, C. S., Jarmain, C., Clulow, A., Mengistu, M., Geldenhuys, C. J., Wise, R., Scholes, R. J., Archibald, S., and Savage, M. J.: Water-use in relation to biomass of indigenous tree species in woodland, forest and/or plantation conditions, Water Research Commission Report No. 361/08, ISBN 978-1-77005-744-9, Pretoria, South Africa, 156 pp., 2008.

Eeley, H. A. C., Lawes, M. J., and Piper, S. E.: The influence of climate change on the distribution of indigenous forest in KwaZuluNatal, South Africa, J. Biogeogr., 26, 595-617, 1999.

Everson, C. S., Burger, C., Olbrich, B. W., and Gush, M. B.: Verification of estimates of water use from riverine vegetation on the Sabie river in the Kruger National park, Water Research Commission Report No. 877/1/01, ISBN 1-86845-781-8, Pretoria, South Africa, 88 pp., 2001.

Everson, C. S., Gush, M. B., Moodley, M., Jarmain, C., Govender, M., and Dye, P.: Effective management of the riparian zone vegetation to significantly reduce the cost of catchment management and enable greater productivity of land resources, Water Research Commission Report No. 1284/1/07, ISBN 978-177005-613-8, Pretoria, South Africa, 92 pp., 2008.

Everson, C. S., Dye, P. J., Gush, M. B., and Everson, T. M.: Water use of grasslands, agroforestry systems and indigenous forests, Water SA, 37, WRC 40-Year Celebration Special Edition 2011, 2011.

Federer, C. A.: A soil-plant-atmosphere model for transpiration and availability of soil water, Water Resour. Res., 15, 555-562, 1979.

FIEC: Guidelines for environmental conservation management in commercial forests in South Africa, Forestry Industry Environmental Committee, Forest Owners Association, Johannesburg, South Africa, 1995.

Gee, G. W., and Bauder, J. W.: Particle-size analysis, in: Methods of Soil Analysis, Part 1-Physical and Mineralogical Methods, edited by: Klute, A., Agronomy Monograph No. 9, 2nd Edn., American Society of Agronomy/Soil Science Society of America, Madison, WI, USA, 1986.

Grainger, M. J. and van Aarde, R. J.: Is Succession-based management of coastal dune forest restoration valid?, Ecol. Restor., 30, 200-208, 2012.

Granier, A., Loustau, D., and Bréda, N.: A generic model of forest canopy conductance dependent on climate, soil water availability and leaf area index, Ann. For. Sci. 57, 755-765, 2001.

Grip, H., Halldin, S., and Lindroth, A.: Water use by intensively cultivated willow using estimated stomatal parameter values, Hydrol. Process., 3, 51-63, 1989.

Grobler, L. E. R.: The Impact of subsistence banana (Musa paradisiaca) farming on the vegetation of peat swamp forest surrounding the Kosi Bay Lake System, BSc. Hons. thesis, University of Pretoria, South Africa, 2004.

Grobler, L. E. R.: A phytosociological study of Peat Swamp Forests in the Kosi Bay lake system, Maputaland, South Africa, MSc dissertation, University of Pretoria, South Africa, 2009.

Grundling, P. L. and Grobler, R.: Peatlands and mires of South Africa, Stapfia 85, zugleich Kataloge der Oö', Landesmuseen Neue Serie 35, 379-396, 2005.

Grundling, P., Mazus, H., and Baartman, L.: Peat resources in northern KwaZulu-Natal wetlands: Maputaland, Department of Environmental Affairs and Tourism Report no. A25/13/2/7, Pretoria, South Africa, 102 pp., 1998. 
Gush, M. B. and Dye, P. J.: Water use measurements of selected woodland tree species within the Kruger National Park, in: Proceedings of the 4th Natural Forests and Savanna Woodlands Symposium, Port Elizabeth, 15-18 May 2006, 387 pp., 2006.

Gush, M. B. and Dye, P. J.: Water-use efficiency within a selection of indigenous and exotic tree species in South Africa as determined using sap flow and biomass measurements, Acta Hort. ISHS, 846, 323-330, 2009.

Gush, M. B., Scott, D. F., Jewitt, G. P. W., Schulze, R. E., Lumsden, T. G., Hallowes, L. A., and Görgens, A. H. M.: Estimation of streamflow reductions resulting from commercial afforestation in South Africa, Water Research Commission Report No. TT173/02, Pretoria, South Africa, 2002.

Hirano, T., Segah, H., Harada, T., Limin, S., June, T., Hirata, R., and Osaki, M.: Carbon dioxide balance of a tropical peat swamp forest in Kalimantan, Indonesia, Global Change Biol., 13, 412425, 2007.

Hoekstra, A. Y.: Water neutral: reducing and offsetting the impacts of water footprints, Value of water research report series no. 28, UNESCO-IHE Institute for Water Education, Delft, The Netherlands, 2008.

James, A., Gaston, K. J., and Balmford, A.: Can We Afford to Conserve Biodiversity?, Bioscience, 51, 43-52, 2001.

Jauhiainen, J., Takahashi, H., Heikkinen, J. E. P., Martikainen, P. J., and Vasander, H.: Carbon fluxes from a tropical peat swamp forest floor, Global Change Biol., 11, 1788-1797, 2005.

Jewitt, G.: Integrating blue and green water flows for water resources management and planning, Phys. Chem. Earth, Parts A/B/C, 31, 753-762, 2006.

Klute, A. and Dirksen, C.: Hydraulic Conductivity and Diffusivity: Laboratory Methods, Methods of Soil Analysis: Part 1- Physical and Mineralogical Methods, sssabookseries, 687-734, 1986.

Kunz, R. P.: Daily rainfall data extraction utility user manual Version 1.4., Institute for Commercial Forestry Research, Pietermaritzburg, South Africa, 2004.

Laclau, J.-P., Arnaud, M., Bouillet, J.-P., and Ranger, J.: Spatial distribution of Eucalyptus roots in a deep sandy soil in the Congo: relationships with the ability of the stand to take up water and nutrients, Tree Physiol., 21, 129-136, 2001.

Landsberg, J. J. and Waring, R. H.: A generalised model of forest productivity using simplified concepts of radiation-use efficiency, carbon balance and partitioning, Forest Ecol. Manage., 95, 209-228, 1997.

Ledieu, J., De Ridder, P., De Clerck, P., and Dautrebande, S.: A method of measuring soil moisture by time-domain reflectometry, J. Hydrol., 88, 319-328, 1986.

Linacre, E. T.: Swamps, 329-347, in: Vegetation and the Atmosphere, Case Studies, edited by: Monteith, J. L., Academic Press, London, . 2, 439 pp., 1976.

Lynch, S. D.: Development of a raster database of annual, monthly and daily rainfall for Southern Africa, Water Research Commission Report No. 1156/1/04, Water Research Commission, Pretoria, South Africa, 78 pp., 2004.

MacKay, F., Cyrus, D., and Russell, K. L.: Macrobenthic invertebrate responses to prolonged drought in South Africa's largest estuarine lake complex, Estuar. Coast. Shelf Sci., 86, 553-567, 2010.

Marshall, D. C.: Measurement of sap flow in conifers by heat transport, Plant Physiol., 33, 385-396, 1958.
Meadows, M. E.: Biogeography and ecosystems of South Africa, Juta and Company Ltd., Cape Town, South Africa, xii + 165 pp., 1985.

Meinzer, F. C., James, S. A., and Goldstein, G.: Dynamics of transpiration, sap flow and use of stored water in tropical forest canopy trees, Tree Physiol., 24, 901-909, 2004.

Meiresonne, L., Nadezhdin, N., Cermak, J., Van Slycken, J., and Ceulemans, R.: Measured sap flow and simulated transpiration from a poplar stand in Flanders (Belgium), Agr. Forest Meteorol., 96, 165-179, 1999.

Mucina, L. and Rutherford, M. C. (Eds.): The Vegetation of South Africa, Lesotho and Swaziland, Strelitzia 19, South African National Biodiversity Institute, Pretoria, South Africa, 2006.

Oren, R., Phillips, N., Ewers, B. E., Pataki, D. E., and Megonigal, J. P.: Sap-flux-scaled transpiration responses to light, vapor pressure deficit, and leaf area reduction in a flooded Taxodium distichum forest, Tree Physiol., 19, 337-347, 1999.

Page, S. E., Rieley, J. O., Shotyk, W., and Weiss, D.: Interdependence of peat and vegetation in a tropical peat swamp forest, Proc. R. Soc. Lond. B., 354, 1885-1897, 1999.

Page, S. E., Siegert, F., Rieley, J. O., Boehm, H.-D. V., Jaya, A., and Limin, S.: The amount of carbon released from peat and forest fires in Indonesia during 1997, Nature, 420, 61-65, 2002.

Perry, J. N.: Fitting split-lines to ecological data, Ecol. Entomol., 7, 421-435, 1982.

Peter, C. I.: Water requirements and distribution of Ammophila arenaria and Scaevola plumieri on South African coastal dunes, M.Sc. Thesis, Rhodes University, Grahamstown, South Africa, 2000.

Peter, C. I. and Ripley, B. S.: An empirical formula for estimating the water use of Scaevola plumieri, S. Afr. J. Sci., 96, 593-596, 2000.

Peter, C. I., Ripley, B. S., and Robertson, M. P.: Environmental limits to the distribution of Scaevola plumieri along the South African coast, J. Vegetat. Sci., 14, 89-98, 2003.

Pooley, E.: The complete field guide to trees of Natal, Zululand \& Transkei, Natal Flora Publications Trust, Durban, South Africa, 2003.

Rieley, J. O. and Ahmed-Shah, A. A.: The vegetation of tropical peat swamp forests, in: Tropical lowland peatland of Southeast Asia, edited by: Maltby, E., Immirzi, C. P., and Safford, R. J., IUCM, Gland, Switzerland, 55-73, 1996.

Ripley, B. S. and Pammenter, N. W.: Do low standing biomass and leaf area index of sub-tropical coastal dunes ensure that plants have an adequate supply of water?, Oecologia, 139, 535-544, 2004.

Ritchie, J. T.: Model for predicting evaporation from a row crop with incomplete cover, Water Resour. Res., 8, 1204-1213, 1972.

Ritsema, C. J. and Dekker, L. W.: Soil moisture and dry bulk density patterns in bare dune sands, J. Hydrol., 154, 107-131, 1994.

Roberts, J., Cabral, O. M. R., Fisch, G., Molion, L. C. B., Moore, C. J., and Shuttleworth, W. J.: Transpiration from an Amazonian rainforest calculated from stomatal conductance measurements, Agr. Forest Meteorol., 65, 175-196, 1993.

Robinson, M. F., Heath, J., and Mansfield, T. A.: Disturbances in stomatal behaviour caused by air pollutants, J. Exp. Botany, 49, 461-469, 1998.

Ruiz-Jaen, M. C. and Mitchell Aide, T.: Restoration Success: How Is It Being Measured?, Restor. Ecol., 13, 569-577, 2005. 
Savage, M. J., Everson, C. S., and Metelerkamp, B. R.: Evaporation measurement above vegetated surfaces using micrometeorological techniques, Water Research Commission Report No. 349/1/97, ISBN 1-86845 363 4, Water Research Commission, Pretoria, South Africa, 248 pp., 1997.

Schulze, R. E., Maharaj, M., Warburton, M. L., Gers, C. J., Horan, M. J. C., Kunz, R. P., and Clark, D. J.: South African Atlas of Climatology and Agrohydrology, Water Research Commission Report No. 1489/1/08, Water Research Commission, Pretoria, South Africa, 2008.

Stone, E. L. and Kalisz, P. J.: On the maximum extent of tree roots, Forest Ecol. Manage., 46, 59-102, 1991.

Suzuki, S., Ishida, T., Nagano, T., and Wijaroen, S.: Influences of deforestation on carbon balance in a natural tropical peat swamp forest in Thailand, Environ. Control Biol., 37, 115-128, 1999.

Swanson, R. H. and Whitfield, D. W. A.: A Numerical Analysis of Heat Pulse Velocity Theory and Practice, J. Exp. Botany, 32, 221-239, 1981.

Sykes, M. T. and Wilson, J. B.: An experimental investigation into the response of some New Zealand sand dune species to salt spray, Ann. Bot., 62, 159-166, 1988.

Taylor, R.: The Greater St. Lucia Wetland Park, Parke-Davis, 1991.

Taylor, R., Kelbe, B., Haldorsen, S., Botha, G. A., Wejden, B., Vaeret, L., and Simonsen, M. B.: Groundwater-dependent ecology of the shoreline of the subtropical Lake St. Lucia estuary, Environ. Geol., 49, 586-600, 2006.

Thomson, S. J. and Armstrong, C. F.: Calibration of the Watermark model 200 soil moisture sensor, Appl. Eng. Agric. 3, 186-189, 1987.

Topp, G. C., Davis, J. L., and Annan, A. P.: Electromagnetic determination of soil water content: Measurements in coaxial transmission lines, Water Resour. Res., 16, 574-582, 1980.

van Aarde, R. J., Coe, M., and Niering, W. A.: On the rehabilitation of coastal dunes of KwaZulu-Natal, S. Afr. J. Sci., 92, 122-124, 1996.
Venter, C. E.: The vegetation ecology of Mfabeni peat swamp, St. Lucia, KwaZulu-Natal, Unpublished MSc. thesis, Faculty of Natural and Agricultural Science, University of Pretoria, Pretoria, South Africa, 140 pp., 2003.

von Maltitz, G., Mucina, L., Geldenhuys, C. J., Lawes, M. J., Eeley, H., Aidie, H., Vink, D., Fleming, G., and Bailey, C.: Classification system for South African Indigenous Forests, An objective classification for the Department of Water Affairs and Forestry, Unpublished report, No. ENV-P-C 2003-017, Environmentek, CSIR, Pretoria, 275 pp., 2003.

Vrdoljak, S. M. and Hart, R. C.: Groundwater seeps as potentially important refugia for freshwater fishes on the Eastern Shores of Lake St. Lucia, KwaZulu-Natal, South Africa, Afr. J. Aquat. Sci., 32, 125-132, 2007.

VSN International: GenStat for Windows 14th Edition, VSN International, Hemel Hempstead, UK, available at: GenStat.co.uk (last access: 24 January 2013), 2011.

Wassenaar, T. D., van Aarde, R. J., Pimm, S. L., and Ferreira, S. M. Community convergence in disturbed subtropical dune forests, Ecology, 86, 655-666, 2005.

Wessels, N. G.: Aspects of the ecology and conservation of swamp forests in South Africa, Unpublished M. Tech thesis, Port Elizabeth Technikon, Port Elizabeth, South Afrifca, 155 pp., 1997.

Whitfield, A. K. and Taylor, R. H.: A review of the importance of freshwater inflow to the future conservation of Lake St. Lucia, Aquat. Conserv. Mar. Freshwat. Ecosyst., 19, 838-848, 2009.

Williams, M., Bond, B. J., and Ryan, M. G.: Evaluating different soil and plant hydraulic constraints on tree function using a model and sap flow data from ponderosa pine, Plant, Cell Environ., 24, 679-690, 2001.

Wösten, J. H. M., Clymans, E., Page, S. E., Rieley, J. O., and Limin, S. H.: Peat-water interrelationships in a tropical peatland ecosystem in Southeast Asia, Catena, 73, 212-224, 2008.

Wullschleger, S. D., Hanson, P. J., and Todd, D. E.: Transpiration from a multi-species deciduous forest as estimated by xylem sap flow techniques, Forest Ecol. Manage., 143, 205-213, 2001. 